\title{
SAFETY MANAGEMENT AS A SUPPORT ACTIVITY IN THE LOCAL SELF-GOVERNMENT
}

\author{
Ján Mišík, ${ }^{1}$ Jozef Kubás²
}

\begin{abstract}
A prerequisite for performance of self-government and its integral components is the government's ability to adequately execute self-governance, which is essential for its efficiency and thus, the meaning of its existence. In villages, in addition to the main activities, a number of supporting activities are carried out to ensure smooth functioning of the core business. Among the supporting activities for municipalities is safety management. The current management guidelines and processes of many municipalities cover components of safety management, but not in a systematic approach. The adoption of an 'official' process of safety management realizes the need for a critical review of their existing practices and its process in the field of security. This contribution deals with the issue of safety management and the responsible roles for creating a safety management system of a village. The purpose of such a system is to ensure the safety of all operations involved in achieving village objectives and to prevent security threats to life, property, and the environment. This contribution mainly focuses on the safety sector of municipalities, which forms the core of the safety management system of a village.
\end{abstract}

JEL Classification Numbers: H83, R11; DOI: http://dx.doi.org/10.12955/cbup.v5.1015

Keywords: efficiency of local self-government, safety management

\section{Introduction}

There are currently several non-military security risks that exist worldwide and each is capable of causing serious harm. These risks affect every reference point within a state and villages within a state need protection. Local authorities have an important role in protecting life, health, property, rights, and freedoms of citizens of villages and towns.

Preventing security threats to life, property, the environment and ensuring safety all rounds to achieve government objectives center on two primary activities:

- Protection of persons and property in emergency situations

- Additional strategies to maintain the security of individuals, property, and the village environment

In small villages, where the issue of safety is less extensive, both sets of activities are the responsibility of either the Mayor within the municipal council or the commander of the voluntary fire brigade of the village (where established).

In larger municipalities, this issue is much more complex requiring more organizations and officials. The primary and irreplaceable role, however, still involves the Mayor and some members of the (city) council who deal with security in creating and commissioning the municipal council.

A large part of village security is administered by the crisis management community, which has a primary aim of preventing and resolving emergency situations. For this group, responding to major emergencies (natural disasters, accidents, disasters, public health threats, and second degree and terrorist attacks) while ensuring citizens' constitutional rights to life, health, property, and the environment, imposes ever increasing demands.

In addition to the components of crisis management community, many safety problems are usually allocated to municipal police, who deal with crisis situations and any other types of security that cannot be easily resolved. Moreover, the crisis management organizations and municipal police are not always clear on their respective responsibilities, and therefore, this study focuses on reviewing this issue to seek possible ways of:

- safety management including areas other than crisis management, and

- solutions and cooperation between the components.

\section{Methods}

Used methods were analysis, synthesis, comparison, induction, deduction and logical thinking, the main source of information was drawn from of available professional literature and to use the acquired knowledge during the study of the given topic.

\footnotetext{
${ }^{1}$ Faculty of Security Engineering, University of Žilina, Slovakia, jan.misik@ fbi.uniza.sk

${ }^{2}$ Faculty of Security Engineering, University of Žilina, Slovakia, jozef.kubas@ fbi.uniza.sk
} 


\section{Results}

In Slovakia villages, a large number of main and supporting activities, in practical terms, is carried out by the authorities in control of the village to achieve administrative objectives. The main activities are determined by the purpose for which the municipality is formed as an organization.

To improve competence, the main activities for the village include:

- Management - planning, organizing, staffing, and monitoring

- Planning, budgeting, and design

- Asset management (asset and municipal facilities)

- General administration

- Services

- Business and investment activity

- Procurement, marketing management

- Transportation

- Other main activities

In a village, a number of supporting activities are performed to ensure proper functioning of the main activities listed above. These include the following particular areas:

- The safety and security of persons, property, and the environment

- Crisis management

- Human resource management

- Quality management

- Information, technology, and telecommunications.

- Operation, maintenance, and servicing of structures, and technological equipment

- Energy security

- Emergency services and other activities

- Other support activities

The safety of the village involves all activities aimed at protecting the interests of all subjects and the village itself. The overall safety includes safety of the village outside the period of crisis management as well as preventing and managing crises.

Both of these profiles contain different areas of security that ultimately create the conditions for the overall safety of the village. These individual safety areas can be grouped into security subsectors for the village (Mišík, 2016).

\section{Safety of the Village outside the Period of Crisis Management}

The subsector of safety for the village

When outside the term of crisis management is part of the security for the village that consists of areas needing continuous and improved monitoring on a daily basis. Figure 1 shows the security for the village when outside the period of crisis management.

\begin{tabular}{|c|c|c|}
\hline The safety of persons and property & The safety of the environment & Security of business \\
\hline $\begin{array}{ll}\text { - } & \text { Physical security (of persons } \\
\text { - } & \text { Ond property) } \\
\text { - } & \text { Opcupational safety and health } \\
\text { - } & \text { Information safety } \\
\text { - } & \text { Computer security } \\
\text { - } & \text { Security \& Protection Rules }\end{array}$ & $\begin{array}{ll} & \text { General protection of } \\
\text { nature } \\
\text { - } & \text { Special environmental } \\
\text { protection } \\
\text { - } \\
\text { Protection of cultural } \\
\text { monuments }\end{array}$ & $\begin{array}{ll}\text { - } & \text { Economic security } \\
\text { - } & \text { Financial Security } \\
& \text { production of } \\
\text { - } & \text { Project safety } \\
\text { - } & \text { Protection against } \\
& \text { fraud and abuse }\end{array}$ \\
\hline
\end{tabular}

The starting point for physical security is with the rights of inhabitants of the village in requesting cooperation to protect their persons, their families, and property located in the village.

An abnormally critical component of security is the physical safety of public property used for village activities. The municipal property should be cultivated, recovered, and its overall policy values 
maintained unabated. Municipal property can be used for general purposes, the municipalities' selfgovernance performance, and business.

Where the municipality uses their property for business purposes, business security is pertinent. Business security involves the village authorities (even where only marginal), for example, the economic committee of the municipal council and the Department of Finance and Accounting.

The safety and health security area at work stem from the competence of departments and municipalities protecting the health conditions and healthy way of life and work for village inhabitants. It also applies to the municipality as an employer. Some municipalities establish a commission for occupational health and safety and fire protection.

Safety of operation in the village includes security of business continuity, especially with utilities and services (municipal waste management, adherence to cleanliness in the village, management, and maintenance of public green areas and public lighting, water supply, and similar services). For operational safety, the management and cleaning of local roads, sidewalks, and public spaces, for example, snow shoveling, are also included. An operational safety issue in the village involves professional technical services and components of crisis management of the village.

Information safety in the village consists of securing information systems of public administration and of important data (e.g., personal data protection and protection of taxation privacy). The village leads the register and performs verification of documents and signatures on all documents, and decides in matters of local taxes and charges, and whether to manage them.

The community processes personal data. The village uses various software tools in which, for example, are kept records of residents, a permanent list of voters, registration of taxpayers, accounting, local taxes and fees, public property, personnel and payroll, and similar data.

Information safety in a village is related to computer security since information and communication technologies that allow electronic records, store, search, process, transmit, and disseminate information are often used in the municipalities.

Safety and protection of internal order of a village are the responsibility of the municipality to provide for regulation of activity, the implementation of which is prohibited or restricted for a given moment or in a certain place. Safety and internal order are solved through regulations by the village Mayor of the municipal council. The advisory organization is the Legislative Committee of the village where established.

Area of environmental safety of a village stems from the obligation to protect the environment of the village. The village provides the protection of cultural heritage. The village has to shape all the conditions necessary for the conservation, protection, restoration, and use of monuments in the municipality. The Monuments Fund is an important part of the cultural heritage, and the village provides maintenance and administers cultural monuments, historic sites, and monuments of the village.

The situation in many municipalities is one where the economic potential of municipalities lags behind, compared to the actual requirements of its development. Under this influence, existing towns and villages have pressures that limit the number of members in the municipal police force, even when there are protracted radical views on its abolition. Therefore, it is imperative that the extensive opportunities for the development of municipal police are depleted, and it is necessary to find new intense forms in their work to ensure their sustainable mission (Belan, 2015).

\section{Crisis Management in the Village}

Crisis management is another significant social concern. Municipalities should provide the necessary immediate assistance to the population in case of an emergency. The village contains the crisis management organization. Organizational units of the municipality in crisis management focus on addressing safety and security threats in the period of threat or periods of action for major events against life, health or property. In these periods their activity mainly focuses on solving crisis management in the case of a fire, flood, major industrial accidents, or other similar emergencies.

The village in its territory:

a) establishes the crisis staff

b) coordinates the activities businesses and legal entities in civil emergency planning 
c) implements measures to deal with crisis situations

d) carries out civil emergency planning

e) oversees other activities

Table 2 shows the organizational units of crisis management at the local level. Table 2: Organizational units of crisis management on the local level

\begin{tabular}{|c|c|}
\hline Governing organs & Efficient elements of rescue systems \\
\hline $\begin{array}{ll}- & \text { Crisis staffs municipalities } \\
- & \text { Business subject (crisis staff, emergency crews) }\end{array}$ & $\begin{array}{ll}\text { - } & \text { Fire service } \\
\text { - } & \text { Civil protection } \\
\text { - } & \text { Medical firs aid }\end{array}$ \\
\hline
\end{tabular}

Source: Authors

This study assumed all aspects of security of the village were integrated into one system, which would have a structure for centralized management, and facilitate the management of the security in an efficient and effective manner (Mišík, Štofko, 2016). Security is a matter for the whole organization. Thus, it should be centrally managed. An organization's management must decide how it wants to deal with a security or safety management system that will be implemented in the organization and how it will assess the state of security and shape its future development. The overall management of larger, more complex organizations improves with the continuous integration of a safety management system (Sennewald, 2003). An Integrated Safety Management System (ISMS) is a single cohesive system for centralizing management of all security structures and processes to meet the security objectives of the organization and satisfaction of all interested parties (Štofková, 2015).

\section{Conclusion}

The security sector of the village consists of several different areas of safety with two main subsectors: 1) the safety of the village when outside the period of crisis management, and 2) crisis prevention and management.

The safety of the village when outside the period of crisis management is usually allocated to the municipal police, who are not always able to deal with all types of security. Crisis management components of municipalities are aimed at preventing and dealing with emergencies.

This system combines all components related to the safety organization for easier management and operation. It is not a common connection of separate systems, but rather their integration, with the mutual connection so that their structure and processes are continuously managed and carried out without duplication.

An introduction of an ISMS to the municipality will allow for efficient operation of security personnel and the use of local sources, as well as the achievement of safety targets for municipalities in various areas of the security sector. This system can assign the responsibility for various areas of the security sector and will adhere to the norms and rules of safety. It would coordinate activities of the various security forces of municipalities, establish internal safety standards in all areas of activity, and provide continuous management of security risks, as well as a comprehensive system of protection to safeguard the security and protection of life, health, property, the environment, and other important municipalities. As well, it would reduce security incidents and support internal and external communications about security issues.

\section{Acknowledgements}

This paper was undertaken, as part of the research project: VEGA 1//0733/15 and 1/0693/16, and IGP 201607 and 201610.

\section{References}

Belan, L. (2015). Security Management: Managing Security. Žilina: EDIS.

Mišík, J. (2016). The Development of the Euroregion Beskydy. Security sector of organization (p. 70-76). Žilina: EDIS.

Mišík, J., Štofko, S., Belan, L. (2016). Architecture of Security Management in Organizations. Interdisciplinarity in theory and practice, 9-13. ISSN 2344-2409.

Sennewald, C. A. (2003). Effective Security Management. Fourth edition. (USA): Elsevier-Science.

Štofková, J., Madleňák, R., Štofková Repková, K. (2015). Business Management. Bratislava: Dolis. ISBN 978-80-970419-77. 